\title{
Characterization of Soybean [Glycine max (L.) Merr.] Mutant Lines
}

\author{
Isma Lestari ${ }^{1}$, Diana Sofia Hanafiah ${ }^{2}$, Emmy Harso Khardinata ${ }^{3}$, Irda Safni ${ }^{4}$, Lutfi Azis \\ Mahmud Siregar ${ }^{5}$ \\ \{ismalestari67@gmail.com¹ ${ }^{1}$ dedek.hanafiah@yahoo.co.id ${ }^{2}$, mamick960@gmail.com ${ }^{3}$ \} \\ Agroecotechnology Departement, Faculty of Agriculture, Universitas Sumatera Utara ${ }^{1,2,3,4,5}$
}

\begin{abstract}
One way to increase soybean production is to develop superior varieties. Development of superior varieties can be done through mutation techniques. Identification of superior varieties is a technique to determine whether what is being faced is the intended variety and characterization aims to produce plant descriptions. This research was conducted by descriptive analysis using the International Union for the Protection of New Varieties of Plants (UPOV). The line numbers used are M100A25 (2/7), M100A25 (3/4), M100A25 (3/7), M200A17 (18/5), M200A12 (6/5), M200A11 (32/3), M100A17 (18/5), M200A17 (13/7), M200A12 (6/5), and Anjasmoro comparison varieties. Morphological characterization is an observation of physical appearance that can be seen and measured such as hypocotyl color, feather color and flowering time. Morphological characterization has a disadvantage that is not necessarily showing the actual genetic diversity, due to environmental factors that affect plant morphology.
\end{abstract}

Keywords: characterization, morphology, soybean

\section{Introduction}

Soybean is the most important strategic food crop after rice and corn. Consumption of soy by the Indonesian people will certainly continue to increase annually considering some considerations such as population growth, increased per capita income, and public awareness of food nutrition [1]. This was strengthened by the analysis of soybean consumption 20162020 by Bapennas [2] stating the demand for soybeans every capita in 2016-2020 was expected to continue to increase, the average every year increased by $14.79 \%$

The widespread projection of soybean crop harvest up to five years (2016-2020) is expected to decrease, on average down $2.90 \%$ every year [2]. According to the data of the Central Statistics agency [3], soybean production is decreasing in 2015-2017 that in 2015 soybean production reaches 963.183 tons, in 2016 the soybean production reaches 859.653 tons and continues to decline until the year 2017 which is only Reaches 538.728. Soybean production is not yet able to meet national needs. Fulfillment of national soybean needs is filled with imports that tend to increase annually [3].

One of the ways in increasing soybean production is by developing soybean-superior varieties. The development of varieties aims to obtain new varieties that have superior properties in accordance with the wishes of farmers. These superior properties include high productivity, short-term, pest-proof, adaptive to specific, and or have the advantages of certain compounds [4]. 
The assembly of soybean's superior varieties is a dynamic activity and the syndicate, breeding procedure starts from increasing the diversity of plants through various means such as crosses, gene transformation, and mutation. After that proceed with selection That use a variety of methods (such as bulk methods, pedigrees, SSDS), output power tests, and multilocation tests $[5,6]$.

The introduction of varieties, to maintain the purity so that the uniform and excellence remain, need to study the morphological properties of plants such as growing type, color hypocotyl, color of flowers, fur color, flowering age, and quantitative properties such as crop height, seed size, and leaf size. Introduction or identification of superior varieties is a technique to determine whether the faced is true and the superior varieties are intended [7]. Characterization studies will make it possible to show out patterns of observable variability of the characters, such as quantitative characterization of fruit form also reveals a clear association between the fruit and seed forms. Characterization or identification is a condition of being able to release a new variety [8]. Characterization aims to produce a description of the plant that is important to mean as a guideline in genetic empowerment in breeding programs [9]. The characterization is also used to release varieties, the importance of characterization done to see the unique nature, and other characters of a new variety. Candidate varieties as intended in paragraph (1) can be removed if eligible: B. A complete and clear description is available, for accurate identification and recognition of varieties [10]. Therefore, this research aims to describe varieties from selected lines to be released into new superior varieties.

\section{Research Methods}

The research was conducted in October 2019 until December 2019 in the Pasar 1 Setia Budi Medan. The materials used in this study were the seeds of soybean seed selection results of Pedigri previous research and Anjasmoro as a comparative varietal, NPK fertilizer, insecticide-made of profenos $500 \mathrm{~g} / \mathrm{L}$, bamboo, water and labels. The tools used in this research are metered, Polybag size $10 \mathrm{Kg}$, watering can, cameras, and stationery.

Land preparation, measuring $9 \mathrm{~m}$ x $10 \mathrm{~m}$, filling Polybag, thinning which is performed by leaving one plant per Polybag, fertilization done a week after planting and crop pest control using insecticide-active Profenofos ( $2 \mathrm{~g} /$ Liter of water) is given from the age of 2 weeks. and adjust to the state of the crop. Weeding is done manually and using hoe according to weed conditions in the field. And watering is done according to conditions of soil conditions in the Polybag.

The methods used in this study are roomy observation techniques and direct observation with morphological diversity based on UPOV guidelines parameters: Color hypocotyl, central leaf shape, lateral leaf shape, flowering time (HST), flower color, color Hair and plant growth type [11]. 


\section{Results and Discussion}

Table 1. Description of observation

\begin{tabular}{|c|c|c|c|c|c|c|c|c|}
\hline \multirow[t]{2}{*}{ No. } & \multirow{2}{*}{$\begin{array}{l}\text { Name lines } \\
\text { / varieties }\end{array}$} & \multicolumn{7}{|c|}{ Parameter Observation } \\
\hline & & $\begin{array}{c}\text { color } \\
\text { hypocotyl }\end{array}$ & $\begin{array}{c}\text { central leaf } \\
\text { shape }\end{array}$ & $\begin{array}{c}\text { lateral leaf } \\
\text { shape }\end{array}$ & $\begin{array}{c}\text { flowering time } \\
\text { (DAP) }\end{array}$ & $\begin{array}{c}\text { flower } \\
\text { color }\end{array}$ & $\begin{array}{l}\text { hair } \\
\text { color }\end{array}$ & $\begin{array}{l}\text { type of } \\
\text { growth }\end{array}$ \\
\hline 1 & $\begin{array}{c}\text { M100A25 } \\
(2 / 7)\end{array}$ & Purple & Ovate & $\begin{array}{c}\text { Rounded } \\
\text { ovate }\end{array}$ & $34-35$ & Purple & White & Determinate \\
\hline 2 & $\begin{array}{c}\text { M100A25 } \\
(3 / 4)\end{array}$ & Purple & Elliptical & $\begin{array}{c}\text { Rounded } \\
\text { ovate }\end{array}$ & 34 & Purple & White & Determinate \\
\hline 3 & $\begin{array}{l}\text { M100A25 } \\
(3 / 7)\end{array}$ & Purple & Elliptical & $\begin{array}{l}\text { Rounded } \\
\text { ovate }\end{array}$ & 34 & Purple & White & Determinate \\
\hline 4 & $\begin{array}{l}\text { M200A17 } \\
(18 / 5)\end{array}$ & Purple & Ovate & $\begin{array}{l}\text { Pointed } \\
\text { ovate }\end{array}$ & $33-34$ & Purple & White & Determinate \\
\hline 5 & $\begin{array}{c}\text { M200A } 12 \\
(6 / 5)\end{array}$ & Purple & Elliptical & Trullate & $31-32$ & Purple & White & Determinate \\
\hline 6 & $\begin{array}{l}\text { M200A } 11 \\
(32 / 3)\end{array}$ & Purple & Ovate & $\begin{array}{c}\text { Pointed } \\
\text { ovate }\end{array}$ & $34-35$ & Purple & White & Determinate \\
\hline 7 & $\begin{array}{c}\text { M100A17 } \\
(18 / 5)\end{array}$ & Purple & Elliptical & $\begin{array}{c}\text { Pointed } \\
\text { ovate }\end{array}$ & 35 & Purple & White & Determinate \\
\hline 8 & $\begin{array}{c}\text { M200A } 17 \\
(13 / 7)\end{array}$ & Purple & Elliptical & $\begin{array}{c}\text { Rounded } \\
\text { ovate }\end{array}$ & 35 & Purple & White & Determinate \\
\hline 9 & $\begin{array}{c}\text { M200A } 12 \\
(6 / 5)\end{array}$ & Purple & Ovate & $\begin{array}{c}\text { Pointed } \\
\text { ovate }\end{array}$ & $34-35$ & Purple & White & Determinate \\
\hline 10 & Anjasmoro & Purple & Elliptical & Oval & $35.7-39.4$ & Purple & White & Determinate \\
\hline
\end{tabular}

Note: DAP = days after planting
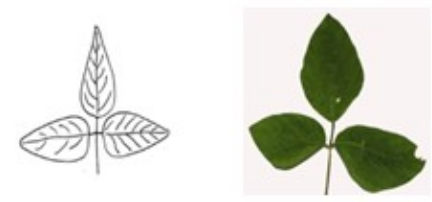

Rounded ovate

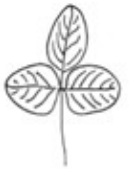

Pointed ovate

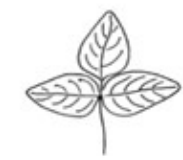

Trullate

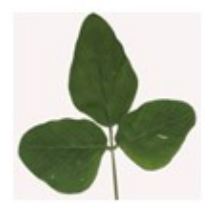

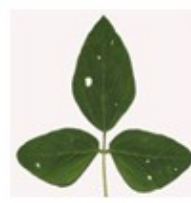
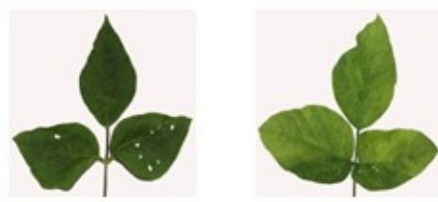

M100A25(3/4)

M100A25(3/7)

M200A $17(13 / 7)$
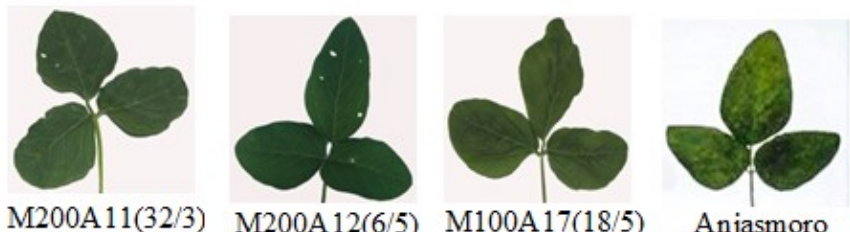

$\mathrm{M} 200 \mathrm{~A} 11(32 / 3)$

M200A12(6/5) M100A17(18/5)

Anjasmoro

Fig 1. Leaf shape of soybean plants 
Plant breeding with gamma-ray mutation is already done in many plants, mutations can occur naturally, but the frequency is very low, also can be done in artificial ways. The planted soybean lines are the result from the induction of gamma-ray radiation of Anjasmoro varieties with a dose of 100 and 200 Gray radiation, the need for characterization or identification of soybean line to find the characteristic and kinship of properties The morphology of the line with its elder. Characterization can be used as a basis in grouping plants this grouping aims to determine the relationship between the plant genotypes and can be taken into consideration in the selection process. Selection through grouping will be effective when the properties of the group can be known [12]. Soybean has two colors hypocotyl that is green and purple, observation color Hypocotyl was can done at age 7 HST-14 HST color Hypocotyl closely related to the color of flowers, can be seen from the research shows the color of purple Hypocotyl will Purple flowers. All varieties of purple hypocotyl are exhibited purple flowers, while green hypocotyl exhibited white flowers [13]. In the treatment of 100 and 200 Gray produces the same hypocotyl color as the older one.

The leaves are the main organ in plants that play directly in photosynthesis and determine optimum photosynthetic capacity through various forms of adaptation mechanisms [14]. The observational character morphology of the leaves is important to know the soybean plant that has certain characteristics for the purpose of improving the character of the leaves of a plant [15]. Observations carried out on primary leaves and lateral leaves, observations of primary leaves were performed at the age of 14 HST and lateral leaves were carried out on the third leaf. The results obtained at line M200A12 (6/5) have a change in the shape of the leaves are Trullate leaves whereas in no line M100A25 (2/7), M100A25 (3/4), M100A25 (13/7) has leaf shape rounded ovate and line M200A17 (18/5), M200A11 (32/3), M200A12 (6/5) and M100A17 (18/5) did not appear to be real different with his elder, Pointed ovate, which refers to his old leaf shape.

Soybean flowers are in perfect flower, pollination occurs when the flower crown is still closed which causes a slight cross-marriage percentage. The flowering time on no line M200A12 (6/5) is categorized as a medium but faster than its old 31-32 HST, line M200A17 (18/5) 33-34 HST, line M100A25 (3/4) and M100A25 (3/7) 34 HST, and on other lines have the same flowering time with the old-35 HST. Factors that affect the age of flower discharge are temperature, duration of illumination and planting time, not all flowers will be pods even though there has been a perfect pollination of about $60 \%$ of the flowers fall before forming pods [16].

In soybean plants can be found a variety of morphological characters such as Trichome scattered throughout the surface of leaves, stems, and pods that vary according to varieties or types of soybeans [17]. Observations include white fur, light brown and dark brown. From the results of the observation of hair color all the lines are similar to the old is white.

Observation of growth type includes growth and indeterminate. The growth type of soybean plant can be determinate and or indeterminate. The pattern of growth between the two types is called semi-determinate, on the type determinate, the vegetative growth stops after the flowering phase [18]. The observation shows that the growth of all lines is the same the as the Elder. 


\section{Conclusion}

Based on the results of the Polymerization it can be seen that the radiation results of 100 Gy and 200 Gy do not significantly affect the character color hypocotyl, flower color, fur color, and the type of growth. For the leaf shape there is a slight difference rounded ovate line M100A25 (2/7), M100A25 (3/4), M100A25 (13/7) and Pointed line M200A17 (18/5), M200A11 (32/64), M200A12 (6/5) and M100A17 (18/5), Line M200A12 (6/5) occur a change in the form of a triangular leaf. For the flowering age there are some lines that are experiencing a quicker change than the elder. The flowering age on the line of M200A12 (6/5) is categorized as a medium but faster than its old-31-32 HST, M200A17 (18/5) 33-34 HST and M100A25 (3/4) and M100A25 (3/7) 34 HST. For further studies it is advisable to identify through molecular genetics.

\section{Acknowledgements}

The author wishes to thank Rector of the Universitas Sumatera Utara and the Indonesian Ministry of Research, Technology and Higher Education, who has supported and funded this research.

\section{References}

[1] Aldillah, R. Projected production and consumption of soybean Indonesia. Journal of Applied Quantitative Economics. (2015).

[2] Data Center and agricultural information systems. Outlook for agricultural commodities, soybean food. Ministry of Agriculture. Jakarta. (2015).

[3] Central Bureau of Statistics. Data of the last 5 years of soybean production according to provincial 2014-2018. Ministry of Indonesia. Jakarta (2018).

[4] Pawiroharsono, S. Biotechnology for Soybean food security: aspects of production and consumption. Bioindustrial Technology Center, assessment Agency and application of technology. Jakarta (2013).

[5] Carsono, N. The role of plant breeding in raising agricultural production in Indonesia. Seminar on Agricultural Sciences. (2008).

[6] Asadi, Soemartono, M. Woerjono, J. Harjosudarmo. The effectiveness of the bulk and pedigree modification selection methods for agronomic characters, the resistance to the Dwarf virus (SSV) F7 of the soy line. Zuriat. (2004).

[7] Gani, J. A. Soybean varieties Superior. Agricultural Information Sheet (LIPTAN), installation research and assessment of agricultural technology, Mataram. (2000).

[8] Hanafiah DS, S Sanggita, Lubis K. Japanese persimmon phenotypic performance (Lf Persimmon) in Karo Regency, North Sumatera, Indonesia. University of North Sumatra. Medan. 
[9] Regulation of The Minister of Agriculture of The Republic of Indonesia Number 61/Permentan/OT. 140/10/2011 Concerning Testing, Assessment, Release and Withdrawal of Varieties. Jakarta. (2011).

[10] Setiamihardja. Inheritance of Pedicel Characters and Their Association to Fruit Characters in Capsicum annum. (1990).

[11] UPOV (Union for the Protection of New Varieties of Plants). Guidelines for the conduct of tests for distinctness, uniformity and stability - Soya Bean (Glycine max (L.) Merr). (2017).

[12] Ansori. F.M., Bambang. S.P., et al. Heritability, characterization, and analysis of the Dihaploid rice line-lines of a Clustergram. IPB. Bogor. (2018).

[13] Gupta A, Mahajan V, Khati P, Srivastava A K. Distinctness in Indian soybean (Glycine max) varieties using DUS characters. Indian Journal of Agricultural Sciences. (2010).

[14] Kisman, et al. Soy adaptation Devolution pattern (Glycine max L. Merrill) against Cekaman Shade based on character Morfo-physiology of Leaf. Bul. Agron. (2008).

[15] Amaliah N, Siti Zubaidah, and Kuswantoro Heru. The diversity of soybeans-lines of Hope (Glycine Max L. Merill) based on the character morphology of the leaves. State University of Malang. Malang. Pros. Seminar Pend. IPA graduate UM. (2017).

[16] Murniarti, E. Simungil soy thousand benefits. (2010)

[17] Painter, R.H. Insect Resistance in Crop Plants. The Macmillan Co. York. (1951).

[18] Adie M M, Ayda Krisnawati. Biological soybean plant. Legume and tuber crops Research Hall. (2016). 